\title{
CHARACTERIZATION OF CANINE LEISHMANIASIS BY PCR-RFLP IN CUIABA, MATO GROSSO, BRAZIL
}

\author{
Arleana do Bom Parto Ferreira Almeida ${ }^{1}$, Daphine Ariadne Jesus de Paula ${ }^{1}$, Valéria

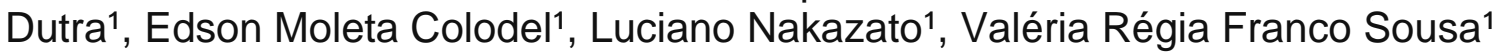 \\ 1 UFMT \\ Correspondência: Arleana Almeida: arleferreira@gmail.com
}

\begin{abstract}
Leishmaniases are neglected zoonoses that are increasing in Brazil. The dog is considered the main reservoir of the visceral form in urban areas of Brazil and also important in maintaining the cycle of transmission of the cutaneous form in endemic areas. We used PCR-RFLP to identify the species of Leishmania involved in canine infection in Cuiaba City, Mato Grosso. Samples of bone marrow and lymph node were collected from 181 dogs, of which $7.2 \%$ tested positive with indirect immunofluorescence and $24.9 \%$ using PCR-RFLP with a significant difference $(P \leq 0.05)$. It was possible to characterize the species Leishmania (L.) chagasi. This will aid in developing prevention measures and in the control of disease in Cuiaba and the surrounding area.
\end{abstract}

Key Words: molecular diagnosis, dog, Leishmania, Mato Grosso

\section{CARACTERIZAÇÃO DA LEISHMANIOSE CANINA POR PCR-RFLP EM CUIABÁ, MATO GROSSO, BRASIL}

RESUMO: Leishmanioses são zoonoses negligenciadas que estão aumentando no Brasil. O cão é considerado o principal reservatório da forma visceral em áreas urbanas do Brasil e também importantes na manutenção do ciclo de transmissão da forma cutânea em áreas endêmicas. Usaram-se PCR-RFLP para identificar as espécies de Leishmania envolvidas na infecção canina na cidade de Cuiabá, Estado de Mato Grosso. Amostras de medula óssea e linfonodos foram coletadas de 181 cães, dos quais $7.2 \%$ foram positivos na imunofluorescência indireta e $24.9 \%$ pela PCRRFLP, com diferença significativa $(P \leq 0,05)$, sendo possível caracterizar as espécies como Leishmania (L.) chagasi. Isso ajuda no desenvolvimento de medidas de prevenção e no controle da doença em Cuiabá e arredores.

Palavras-chave: cão, diagnóstico molecular, Leishmania, Mato Grosso 


\section{INTRODUCTION}

The leishmaniases are a major public health concern, causing cutaneous infections and systemic involvement, and transmitted by sandflies of the genus Lutzomyia in the Americas. Visceral leishmaniasis caused by Leishmania (Leishmania) chagasi (= syn $L$. infantum) is the most serious form of the disease, while cutaneous leishmaniasis in Brazil is caused by infection with Leishmania (Viannia) braziliensis. In recent years, leishmaniasis in Brazil has undergone changes in its epidemiology. Initially, the disease was typically rural but is now an urban zoonosis (Ashford, 2000), with reports of human cases in four regions, due the deforestation and migration to the major population centers (Silva et al., 2005).

Several species of mammals are subject to infection by Leishmania spp in Brazil, but the dog is considered the main reservoir for transmission of $L$. (L.) chagasi (Dantas-Torres, 2007). The serological techniques are recommended for epidemiological investigations by the Ministry of Health in Brazil (MS, 2006). In recent years, PCR has been used as a sensitive and specific technique for detecting DNA of Leishmania in biological samples (Ikonomopoulos et al., 2003).

Mato Grosso State is considered endemic for both visceral and cutaneous leishmaniases, showing an increase in reporting of these diseases (SES-MT, 2008). This study aimed to characterize the species of Leishmania involved in canine leishmaniasis in Cuiaba city by PCR, through the use of restriction enzymes (PCR-RFLP). The identification of the species is important to the control of the disease in this area.

\section{MATERIAL AND METHODS}

Samples of blood, bone marrow, and lymph node were obtained from 181 dogs of various breeds, aged more than six months old and of both sexes, from four districts of Cuiaba, where cases of diseased dogs had been diagnosed at the Veterinary Hospital of the Federal University of Mato Grosso (HOVETUFMT).

The blood, bone marrow and lymph node samples were collected by jugular venipuncture, xiphoid process of the sternum following antisepsis and local anesthesia with $2 \%$ lidocaine and popliteal lymph node, respectively, upon free consent of the pet owner, the latter two were added to $0.5 \mathrm{~mL}$ sterile $0.9 \%$ $\mathrm{NaCl}$, subsequently stored frozen at $20^{\circ} \mathrm{C}$ until use. Indirect immunofluorescence was performed using a commercial kit (BioManguinhos ®/FIOCRUZ) following the manufacturer's directions.

To extract DNA, samples were dissolved in lysis buffer $(10 \mathrm{mM}$ Tris- $\mathrm{HCl}$ $\mathrm{pH}$ 8.0, $25 \mathrm{mM}$ EDTA, $100 \mathrm{mM} \mathrm{NaCl}$, $0.5 \% \mathrm{SDS}$, and $100 \mu \mathrm{g} / \mathrm{ml}$ proteinase $\mathrm{K}$ ), and the mixture incubated at $56^{\circ} \mathrm{C}$ for 12-18 h. DNA was extracted by the phenol-chloroform method and precipitated with isopropanol. After washing in $70 \%$ ethanol for $10 \mathrm{~min}$ at 10 $000 \times \mathrm{g}$, the DNA precipitate was dissolved in ultra pure water (Gomes et al., 2007). The polymerase chain reaction was conducted using the primers 150 (sense) $\quad 5^{\prime}-\mathrm{GGG} \quad(\mathrm{G} / \mathrm{T})$ AGGGGCGTTCT (C/G) CGAA-3 'and 152 (antisense) 5' (C/G) (C/G) (C/G) (A/T) CTAT (A/T) TTACACCAACCCC-3' (Degrave et al., 1994), which amplified a fragment of DNA from a 120 bp region of conserved minicircle kDNA present in all species of Leishmania. The amplification used $200 \mu \mathrm{M}$ of dNTP, $1 \mu \mathrm{M}$ of each primer, buffer solution (10 mM Tris- $\mathrm{HCl}$, $50 \mathrm{mM} \mathrm{KCl}, \mathrm{pH}$ 8.3), $2 \mathrm{mM} \mathrm{MgCl}_{2}, 1.5 \mathrm{U}$ of Taq DNA polymerase, and $5 \mu \mathrm{l}$ of the 
DNA sample in a final volume of $20 \mu \mathrm{l}$. Conditions were one cycle at $94^{\circ} \mathrm{C}$ for 4 min, followed by 30 cycles at $94^{\circ} \mathrm{C}$ for 30 $\mathrm{s}, 56^{\circ} \mathrm{C}$ for $30 \mathrm{~s}, 72^{\circ} \mathrm{C}$ for $30 \mathrm{~s}$, and a final step extension of one cycle at $72^{\circ} \mathrm{C}$ for $10 \mathrm{~min}$. The amplification product was fractionated by electrophoresis in $2.0 \%$ agarose gel stained with ethidium bromide and analyzed in a transilluminator at $300 \mathrm{~nm}$.

PCR-RFLP mkDNA was carried out according to Andrade et al. (2006) with some modifications. Five $\mu$ l of PCR product were digested by $1 \mathrm{U}$ Haelll enzyme and incubated for $3 \mathrm{~h}$ at $37^{\circ} \mathrm{C}$. Restriction fragments were separated in $10 \%$ polyacrylamide gel and stained with ethidium bromide. The fragments obtained were compared with standard strains of $L$. (L.) chagasi (MHOM/BR/74/PP75) and L. (V.) braziliensis (MHOM/BR/75/M2903) from the Oswaldo Cruz Institute/FIOCRUZ, Rio de Janeiro.

Statistical analysis was performed using Epi Info, version 3.3.2 (CDC, Atlanta), through the $X^{2}$ test, adopted significance level was $5 \%$, and Kappa index $(k)$ was calculated for analysis of concordance between tests. Sensitivity (S) and specificity (SP) of PCR were calculated by indirect fluorescent antibody test - IFAT as the gold standard.

\section{RESULTS}

Of the 181 sera tested, $13(7.2 \%)$ showed anti-Leishmania using IFAT. Forty-five dogs (24.9\%) tested positive with PCR. PCR showed a sensitivity of $53.8 \%$ and specificity of $77 \%$ compared with IFAT, with a low correlation between the two tests $(k 0,14)$ and significant difference $\mathrm{P} \leq 0.05$ (Table 1 ). Sensitivity in detection of DNA of Leishmania spp. in an individual dog was significantly higher $(P=0.0039)$ when using bone marrow (37) compared to lymph node for PCR (15).

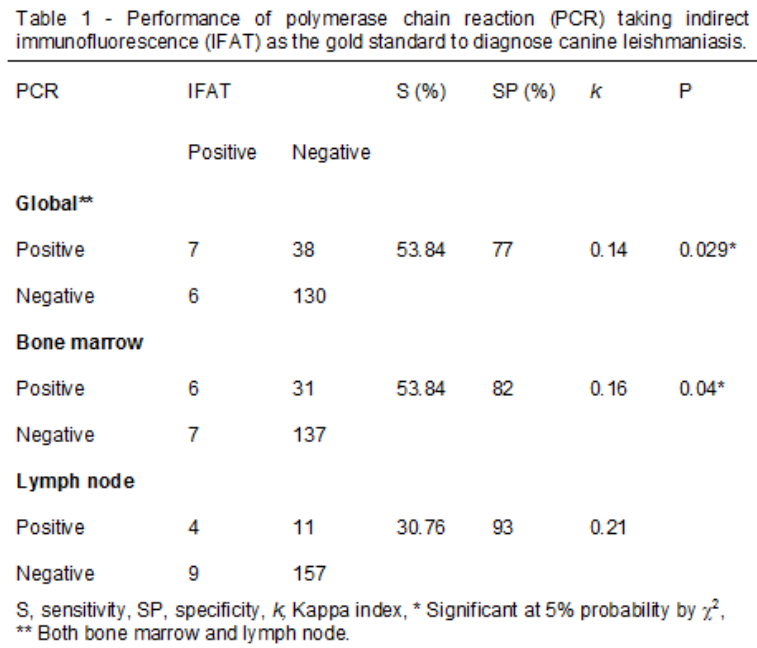

In six dogs showing antibodies detected by IFAT, there was no amplification of DNA of Leishmania sp. The titers of antibodies produced by these animals were 1:40 in four dogs and $1: 80$ and $1: 160$ in the remaining two. In dogs testing positive with PCR, three $(6.7 \%)$ were symptomatic, 11 $(24.4 \%)$ oligosymptomatic and 31 (68.9\%) asymptomatic. In dogs testing positive with IIF the numbers were three, three, and seven, respectively, and these data were not significantly different from $P C R$ results $(P \geq 0.05)$. PCR-RFLP using the restriction enzyme Haelll for identified species in these samples as Leishmania (Leishmania) chagasi.

\section{DISCUSSION}

Serological tests, such as ELISA and IFAT (MS, 2006), are traditionally used in Brazil to estimate the prevalence of leishmaniasis in dogs. These methods have been challenged, since the removal of seropositive dogs has not led to a decrease the occurrence of the disease (Silva et al., 2005). Studies have shown PCR to be effective in the diagnosis of leishmaniasis in dogs and humans (Osman et al., 1997; Fisa et al., 2001). In the present study, PCR detected 45 of 181 (24.9\%) dogs positive for leishmaniasis, compared to $13(7.2 \%)$ using IFAT. The superiority of 
PCR for detection of canine infection has been reported by others (SolanoGallego et al., 2001). The sensitivity and specificity of molecular methods are dependent on the DNA sequences used as primers for PCR. In this study, a pair of primers that amplify a sequence of 120 bp DNA of Leishmania spp. was used which Lachaud et al. (2002) reported to be the most effective in detecting infection of five assessed.

Six seropositive dogs tested negative with PCR; however antibody titration was at the lower limit level. The presence of Leishmania antibodies without detection of DNA may be attributed to antibodies remaining after elimination of the parasite or to a crossreaction with other parasites such as Trypanosoma, as described by Vexenat et al. (1996). However, according to Francino et al. (2006), conventional PCR can result in false negatives when the number of parasites in a sample is small. In this study, the sensitivity of PCR may have been decreased in asymptomatic animals, where samples were of small volume, this was observed by Ikonomopoulos et al. (2003), who mention the ease of blood and bone marrow sample collection and obtained a greater volume of blood offering higher detection of parasite DNA.

The low sensitivity of epidemiological tests contributes to failure in control programs of leishmaniasis because asymptomatic dogs are not eliminated in endemic areas. Clinically, $31(68.9 \%)$ of dogs with the amplification of DNA of Leishmania spp were asymptomatic at the time of collecting biological samples. This was true of nine identified by IFAT $(69.2 \%)$, which was not significantly different. Francino et al. (2006) reported an increased capacity of PCR to detect asymptomatic dogs compared with serologic tests.

Various biological samples may be used in PCR for diagnosis of leishmaniasis (Fisa et al., 2001). Manna et al. (2004) lymph node aspirate showed high sensitivity in diagnosing infection, but in this study the sensitivity of lymph node was significantly lower than bone marrow $(P \leq 0.05)$.

According to Ikonomopoulos et al. (2003) it is more effective to diagnose leishmaniasis by PCR in symptomatic animals, due to the number of organs affected and consequent greater quantity of sample. However, this may difficult in epidemiological investigations with a greater proportion of asymptomatic dogs (Alvar et al., 2004).

In this study, the restriction enzyme Haelll, which, according to Volpini et al. (2004), can identify Leishmania species, indicated the species of Leishmania infecting dogs in Cuiaba to be $L$. (L.) chagasi, the agent of visceral leishmaniasis in Brazil. Despite being a cutaneous Leishmania tropism, L. (V.) braziliensis is often isolated from skin lesions (Madeira et al., 2006). Andrade et al. (2006) identified it in samples of skin, bone marrow, liver and spleen of dogs in Belo Horizonte, Minas Gerais using the technique employed in this study, and demonstrating the higher sensitivity of molecular methods for detecting Leishmania spp infections compared to parasitological methods.

\section{ACKNOWLEDGMENTS}

Dr. Elisa Cupolillo for providing the Leishmania strains used as PCR reference.

\section{INFORMATIVE NOTES}

The project was approved by the Ethical Committee of CEPA-UFMT (process 23108.043642/08.3). 


\section{REFERENCES}

ALVAR, J.; CANAVATE, C.; MOLINA, R. et al. Canine leishmaniasis. Advances in

Parasitology, v.57, n.1, p.1-88, 2004.

ANDRADE, H.M.; REIS, A.B.; SANTOS, S.L. et al. Use of PCR-RFLP to identify Leishmania species in naturally-infected dogs. Veterinary Parasitology, v.140, n.3/4, p.231-238, 2006.

ASHFORD, R.W. The leishmaniases as emerging and reemerging zoonoses. International Journal for Parasitology, v.30, n.12/13, p.269-1281, 2000.

DANTAS-TORRES, F. The role of dogs as reservoirs of Leishmania parasites with emphasis on Leishmania (Leishmania) infantum and Leishmania (Viannia) braziliensis.

Veterinary Parasitology, v.149, n.3/4, p.139146, 2007.

DEGRAVE, W.; FERNANDES, O.; CAMPBELL, D. et al. Use of molecular probes and PCR for detection and typing of Leishmania-a minireview. Memórias do Instituto Oswaldo Cruz, v.89, n.3, p.463-469,1994.

FISA, R.; RIERA, C.; GÁLLEGO, M. et al. Nested PCR for diagnosis of canine leishmaniosis in pheripheral blood, lymph node and bone marrow aspirates. Veterinary Parasitology, v.99, n.2, p.105-111, 2001.

FRANCINO, O.; ALTET, L.; SANCHEZ-

ROBERT, E. et al. Advantages of real-time PCR assay for diagnosis and monitoring of canine leishmaniosis. Veterinary Parasitology, v.137, n.3/4, p.214-221, 2006.

GOMES, A.H.S.; FERREIRA, I.M.R.; LIMA, M.L.S.R. et al. PCR identification of Leishmania in diagnosis and control of canine leishmaniasis. Veterinary Parasitology, v.144, n.3/4, p.234241, 2007.

IKONOMOPOULOS, J.; KOKOTAS, S.; GAZOULI, M. et al. Molecular diagnosis of leishmaniosis in dogs. Comparative application of traditional diagnostic methods and the proposed assay on clinical samples. Veterinary Parasitology, v.113, n.2, p.99-113, 2003.

LACHAUD, L.; MARCHERGUI-HAMMAMI, S.; CHABBERT, E. et al. Comparison of six PCR methods using peripheral blood for detection of canine visceral leishmaniasis. Journal of Clinical Microbiology, v.40, n.1, p.210-215, 2002.

MADEIRA, M.F.; SCHUBACH, A.; SCHUBACH, T.M.P. et al. Mixed infection with Leishmania (Viannia) braziliensis and Leishmania
(Leishmania) chagasi in a naturally infected dog from Rio de Janeiro, Brazil. Transactions of the Royal Society of Tropical Medicine and Hygiene, v.100, n.5, p.442-445, 2006.

MANNA, L.; VITALE, F.; REALE, S. et al. Comparison of different tissue sampling for PCR-based diagnosis and follow-up of canine visceral leishmaniosis. Veterinary Parasitology, v.125, n.3/4, p.251-262, 2004.

Ministério da Saúde, Brasil - MS. Manual de Controle da Leishmaniose Visceral, Ministério da Saúde, Brasília, DF, 2006. 120p.

OSMAN, O.F.; OSKAM, L.; ZIJLSTRA, E.E. et al. Evaluation of PCR for Diagnosis of Visceral Leishmaniasis. Journal of Clinical Microbiology, v.35, n.10, p.2454-2457, 1997.

Secretaria Estadual de Saúde do Estado de Mato Grosso - SES-MT. Número de casos humanos de LV e LT no estado de Mato Grosso (1998-2007). In: Curso Básico de Vigilância Ambiental (CBVA) - Vigilância e Controle da Leishmaniose no Estado de Mato Grosso. Cuiabá, 2008. CD-ROM.

SILVA, A.V.M.; PAULA, A.A.; CABRERA, M.A.A. et al. Leishmaniose em cães domésticos: aspectos epidemiológicos. Cadernos de Saúde Pública, v.21, n.1, p.324-328, 2005.

SOLANO-GALLEGO, L.; MORELL, P.; ARBOIX, $M$. et al. Prevalence of Leishmania infantum in dogs living in an area of canine leishmaniasis endemicity using PCR on several tissues and serology. Journal of Clinical Microbiology, v.39, n.2, p.560-563, 2001.

VEXENAT, A.C.; SANTANA, J.M.; TEIXEIRA, A.R. Cross-reactivity of antibodies in human infectious by the kinetoplastid protozoa Trypanosoma cruzi, Leishmania chagasi and Leishmania (Viannia) braziliensis. Revista do Instituto de Medicina Tropical de São Paulo, v.38, n.3, p.177-185, 1996.

VOLPINI, A.C.; PASSOS, V.M.; OLIVEIRA, G.C. et al. PCR-RFLP to identify Leishmania (Viannia) braziliensis and L. (Leishmania) amazonensis causing American Cutaneous Leishmaniasis. Acta Tropica, v.90, n.1, p.31-37, 2004. 